\title{
Spatial-temporal evolution characteristics and influencing factors of county rural hollowing in Henan
}

\author{
Menghao Yang ${ }^{1,2}$ (D) Zhihong Yao ${ }^{2 *}$ Lianhai Cao $^{2}$ Haipeng Zhang ${ }^{3}$ Jie Huang
}

\begin{abstract}
'Key Laboratory of Soil and Water Loss Process and Control on the Loess Plateau of the Ministry of Water Resources, Zhengzhou, China. ${ }^{2}$ School of Resources and Environment, North China University of Water Resources and Electric Power, 450046, Zhengzhou, China. E-mail: yaozhihong@ncwu.edu.cn. "Corresponding author.

${ }^{3}$ Key Research Institute of Yellow River Civilization and Sustainable Development \& Collaborative Innovation Center on Yellow River Civilization of Henan province, Henan University, Kaifeng, China.
\end{abstract}

\begin{abstract}
Taking Henan province as an example, the index system of rural hollowing was constructed from three aspects of economy, population and land. Using the entropy weight method, hollowing index method, spatial autocorrelation analysis and Geo detector, spatialtemporal evolution characteristics and influencing factors of county rural hollowing from 2000 to 2013 in Henan province were analyzed. Results showed that the gap of rural hollowing between counties in Henan province expanded first and then decrease, and the whole province was at the middle level of rural hollowing, so the development of rural hollowing in Henan province was stable and positive. Spatial variation characteristics of different degrees rural hollowing during 2000-2013 were obvious, and the overall spatial pattern was higher in the northwestsoutheast direction and lower in the northeast-southwest direction. There was a strong spatial positive correlation in rural hollowing, and spatial agglomeration was slightly weakened; the number of counties in $H-H$ and $L-L$ agglomeration areas was large and its agglomeration characteristics were obvious; the H-L agglomeration areas started from zero with a small number and scattered distribution. Influence of different factors on rural hollowing was quite different, and the per capita homestead area, the proportion of secondary and tertiary industries, the investment in fixed assets and the per capita net income of farmers were the dominant factors.
\end{abstract}

Key words: rural hollowing, spatial-temporal evolution, influencing factors. Henanprovince.

Características de evolução espacial e fatores de influência do êxodo rural do condado de Henan

RESUMO: Tomando a província de Henan como exemplo, o sistema de índices de evasão rural foi construído a partir de três aspectos da economia, população e terra. Utilizando o método de peso de entropia, método de índice de vazamento, análise de autocorrelação espacial e Geo detector para analisar características de evolução espaço-temporal e fatores de influência do esvaziamento rural do município de 2000 a 2013 na província de Henan. Os resultados mostraram que a lacuna de esvaziamento rural entre condados na provincia de Henan foi expandida inicialmente e em seguida diminuiu, e toda a província estava no nível médio de evasão rural, e, além disso, o desenvolvimento da evasão rural na província de Henan era estável. As características de variação espacial de diferentes graus de evasão rural durante 20002013 eram óbvias, e o padrão espacial geral era mais alto na direção noroeste-sudeste e mais baixo na direção nordeste-sudoeste. Houve forte correlação positiva espacial no êxodo rural, e a aglomeração espacial foi levemente enfraquecida; o número de municípios nas áreas de aglomeração H-H e L-L era grande e as características de aglomeração eram óbvias; as áreas de aglomeração de H-L eram do zero com um pequeno número e distribuição dispersa. A influência de diferentes fatores no esvaziamento rural foi diferente, e a área de propriedade per capita, a proporção de indústrias secundárias e terciárias, o investimento em ativos fixos e a renda líquida per capita dos agricultores foram os fatores dominantes.

Palavras-chave: escavação rural, evolução espacial, factores de influência, Província de He 'nan.

\section{INTRODUCTION}

Rural hollowing is the result of evolution of rural regional system in the process of urbanrural transformation and development and it is also a relatively common phenomenon in the process of rapid urbanization (LIU et al. 2009; LIU et al. 2010). For example, the decline of rural areas in the process of rapid urbanization in developed countries in Europe and America, and the phenomenon of overthinning of rural areas in the process of urbanization in Japan are all similar to the phenomenon of rural hollowing in China (JIAO,2004; WHITE et al.2009). Rural hollowing is caused by the non-agricultural transfer of rural population. Under the background of disorderly management of rural residential areas, rural 
hollowing is the phenomenon of "outer expansion and inner space" that the scale of rural residential land has been expanding and the problem of empty waste has stood out, caused by building new rural residential areas without demolishing old ones, one household with many houses and exceeding the standard (LIU et al. 2009). China is currently in a critical period of urban-rural transformation and reconstruction. The population flow between urban and rural areas and the reorganization and interaction of social and economic development elements are accelerated(LONG, 2013), which directly leads to the intensification of hollowing phenomenon characterized by the overthinning of the population in rural areas, a large number of abandoned and idle homestead sites, and the lack of economic and industrial development motive force. Even in some areas there are more obvious "rural diseases" (TANG et al. 2014;TIAN et al. 2014). In 2018, The No.1 document of the Central Committee proposed to implement the strategy of rural revitalization, while one of the typical problems faced by rural development was the problem of rural hollowing. Therefore, it is one of the key issues in the implementation of rural revitalization and also a major issue in the research and practice of rural geography that need to be solved urgently to realize the rural hollowing out of China in the new period of the regional differentiation regularity, adapting to the new trend of rural population flow and village change and optimizing rural population, industry and land use space in the process of implementing the strategy of rural revitalization (LIU et al. 2009; LIU, 2018).

At present, the research on rural hollowing mainly includes its connotation and formation mechanism, evolution law and stage characteristics, influence factors and action mechanism, remediation potential and countermeasures, management decision and control, et al(PAN et al. 2013; TAN et al. 2017; LU et al. 2013).For example, CHENG et al. (2001) studied the formation mechanism of rural hollowing in Taiyuan Basin, and put forward five process models reflecting it. LONG et al. (2009) revealed the types and stage characteristics of the evolution of rural hollowing in urban-rural fringe and agricultural areas of plain regain in China from a macro perspective, and analyzed the dynamic mechanism of the evolution by a case study on agricultural areas of plain regain. Based on the door-to-door survey data in village. WANG et al. (2013) calculated the degree of rural hollowing in Shandong province and further analyzed the relationship between rural hollowing and influencing factors. Starting from the three systems of land, population and economy, YANG et al. (2012) measured and divided rural hollowing-out areas in China and provided a more comprehensive index system for the comprehensive measurement of rural hollowing. SONG et al. (2013) analyzed the degree and influencing factors of rural hollowing in different locations and topographic conditions and concluded that the rate of hollowing in the far suburbs of cities and towns was higher than that in the near, and that in mountain villages was higher than that in plain areas and hilly areas. YU et al. (2018) studied the spatial restructuring and land consolidation of urban-rural settlement in Shanghang county of Fujian province based on ecological niche perspective, and discussed the differences between "hollowing villages" in plain areas and "deserted villages" in mountainous areas, and the study significantly extended the understanding of "hollowing village" theory. LIUet al. (2009) revealed the dynamic mechanism of the hollowing out of rural population by using the theory of "push and pull", and combined with the renovation practice of Yucheng city in Shandong province from the geographical point of view, put forward the regulation criterion and concept of hollow village and the mode of "occupy the east and fill the west" and it also proposed the concept of demonstration planning of "small center, big gathering". All these studies have played an important role in supporting the in-depth analysis and renovation of rural hollowing. However, the existing studies mostly stop at the quantitative measurement and regional spatial differentiation of rural hollowing on a single time cross section, while there are few studies on the dynamic analysis of the spatial and temporal changes of rural hollowing on a county scale of a typical province on a multitime cross section. In addition, there is a lack of quantitative analysis on the influencing factors and mechanism of hollowing.

Henan province is a typical populous and agricultural province and it is the key agricultural area of China and bears the heavy responsibility of national and regional grain production. In recent years, with the influx of a large number of rural people into cities and towns, which caused a large number of rural residential land empty and wasted. At the same time, the unreasonable expansion of rural residential land, the rapid expansion of urban space and the reduction of cultivated land by multiple pressure, has seriously threatened food security. Therefore, the problem of rural hollowing is more typical in Henan province and the development of related research is more urgent. Based on this, this research takes Henan province as the research object, carries on the quantitative evaluation of the county area countryside hollowness 
in Henan province, explores its spatial-temporal evolution characteristics, and quantitatively identifies the dominant factor and the influence mechanism of hollowing on the multi-time section, so as to provide a theoretical basis for the management of hollowing in Henan province and provide a reference for the formulation of relevant policies.

\section{MATERIAL AND METHODS}

\section{General situation of study area}

Henan province $\left(31^{\circ} 23^{\prime}-36^{\circ} 22^{\prime} \mathrm{N} 、 110^{\circ} 21^{\prime}-\right.$

$\left.116^{\circ} 39^{\prime} \mathrm{E}\right)$ is located in the middle and east of China and the middle and lower reaches of the Yellow River (Figure 1). Henan province is a populous province and a large agricultural province with 18 municipalities under its jurisdiction. It has a long history of agricultural production and a large rural population. Since 2000, urbanization in Henan province has accelerated and its urbanization rate has increased by 22 percentage points, with an average annual growth rate of $1.57 \%$, which is higher than the national average growth rate of $1.32 \%$. In the past 14 years, the immigration of rural population has reached 14.44 million. In 2014, the urbanization rate of Henan province was of $45.2 \%$, which is lower than the national average of 9.57 percentage points, the development potential of urbanization in the future is large. With the large-scale transfer of rural population to cities and towns, the phenomenon of empty residential land is widespread in rural areas. At the same time, due to the unreasonable expansion of residential areas, in the context of a massive decline of the rural population, the rural residential land in Henan province does not decrease but increase. According to statistics, the area of rural residential areas in Henan province has increased from 1453486 hectares in 2000 to 1597159 hectares in 2014, 143673 hectares were increased in 14 years. The phenomenon of the unused land and outer space in rural areas is very serious, and the situation of cultivated land protection is becoming increasingly grim.

\section{Basic data}

The socio-economic data and land use data of 109 county-level administrative units in Henan province were collected and compiled including the four typical years of 2000, 2005, 2010 and 2013. Socio-economic data was collected and collated according to "Henan Statistical Yearbook", and "China County Statistical Yearbook" and census data in relevant years; the land use data comes from the land use status data set of the corresponding year of the Department of National Resources of Henan Province. The base utilization standards of the County and City Homestead mainly refers to the "Measures for the Implementation of the Land Administration Law of Henan province" and the "Administrative

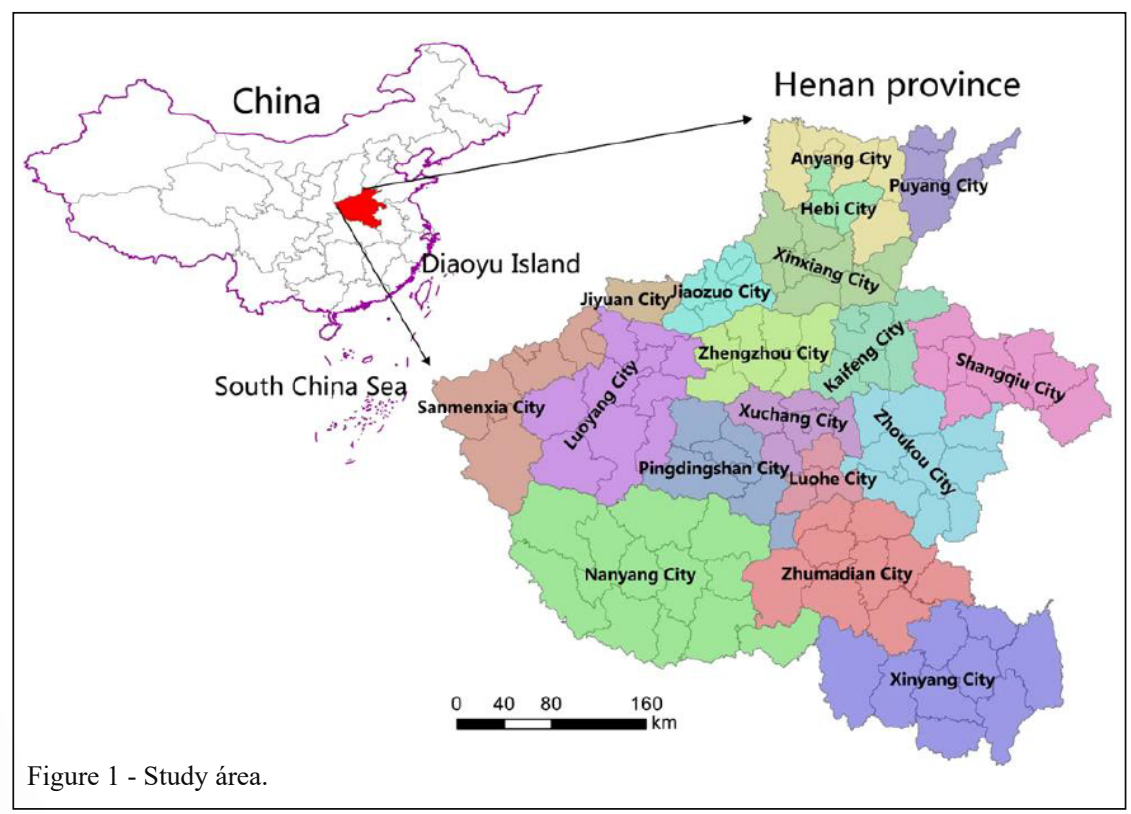

Ciência Rural, v.49, n.4, 2019. 
Measures for Land Use of Rural Homesteads of Henan province".

\section{Research methods}

Construction of Hollow Comprehensive Measurement Index System

Combined with the existing research (PAN et al.2013; TAN et al.2017; LU et al.2013; YANG et al.2012; LI et al.2014), based on the three sub-systems of economy, population and land, a comprehensive index system of rural hollowing in Henan province was constructed (Table 1). Among them, the urbanrural income ratio reflects the difference between urban and rural income levels and the greater the income gap between urban and rural areas can make the stronger the driving force for rural population transfer and the higher degree rural hollowing. The Family population concentration reflects the size of rural households. With the rural family type gradually evolved from the trunk to the multi-core, the smaller family size will occupy more housing land area and the degree rural hollowing will be higher. Semi-urbanization rate of the rural population is an incomplete state of transition from rural population to urban population and it is also a standard to measure the extent of rural population outflow. The higher rural population semi-urbanization rate will bring a greater degree of rural hollowing. The tillage aggregation ratio reflects the relationship between rural cultivated land and residential land. The expansion of residential areas will result in a reduction in the area ofcultivated land, a smaller tillage aggregation ratio and a higher degree rural hollowing.

\section{(1) Standardization of indicators}

In order to eliminate the dimension and ensure the comparability among the indicators, it is necessary to standardize the indicators. The treatment methods are as follows:

Positive index :

$$
y_{i j}=\frac{x_{i j}-\min x_{i j}}{\max x_{i j}-\min x_{i j}}
$$

Negative index

$y_{i j}=\frac{\max x_{i j}-x_{i j}}{\max x_{i j}-\min x_{i j}}$

In the formula: $y_{i j}$ is the standardized value of the jth indicator in region $i, x_{i j}$, is the initial value of the $\mathrm{jth}$ indicator in region $i, \min x_{i j}$ is the minimum of indicator, $x_{i j}, \max x_{i j}$ is the maximum of indicator $x_{i j}$.

\section{(2) Weight determination}

In order to overcome the information overlap among multi-index variables and eliminate the subjectivity of artificial determination of the weight, the entropy weight method is used to determine the weight of the evaluation index of rural hollowing in counties of Henan province. Entropy, a physical concept derived from thermodynamics, has

Table 1 - Comprehensive measurement index system of county rural hollowing in Henan province.

\begin{tabular}{|c|c|c|c|c|c|}
\hline Target layer & Rule layer & Index layer & Index measurement & Effect & Weight \\
\hline \multirow{12}{*}{$\begin{array}{l}\text { Rural } \\
\text { hollowing } \\
\text { degree }\end{array}$} & \multirow{4}{*}{$\begin{array}{l}\text { Economic } \\
\text { subsystem }\end{array}$} & Economic development level & Per capita GDP & + & 0.4604 \\
\hline & & Regional economic structure & Secondary and tertiary/GDP & + & 0.1577 \\
\hline & & Urban-rural income ratio & Rural per capita net income/Urban per capita income & - & 0.1353 \\
\hline & & Farmers' income level & Per capita net income of farmers & + & 0.2466 \\
\hline & \multirow{5}{*}{$\begin{array}{l}\text { Population } \\
\text { subsystem }\end{array}$} & Rural population concentration & Rural population/Rural residential area & - & 0.1993 \\
\hline & & Rural population centrality & Rural population/Number of villages & - & 0.1245 \\
\hline & & $\begin{array}{l}\text { Family population } \\
\text { concentration }\end{array}$ & Rural population/Number of rural households & - & 0.2510 \\
\hline & & $\begin{array}{l}\text { Rural population semi- } \\
\text { urbanization rate }\end{array}$ & $\begin{array}{l}\text { (Agricultural household population-Rural permanent } \\
\text { population)/Agricultural household population }\end{array}$ & + & 0.2265 \\
\hline & & $\begin{array}{l}\text { Effective transfer degree of } \\
\text { rural population }\end{array}$ & Urbanization rate/Rural non-agricultural employment rate & - & 0.1987 \\
\hline & \multirow{3}{*}{$\begin{array}{c}\text { Land } \\
\text { subsystem }\end{array}$} & $\begin{array}{l}\text { Extensive utilization of } \\
\text { homestead }\end{array}$ & $\begin{array}{c}\text { the per capita homestead area/Standard of using Homestead in } \\
\text { County and City }\end{array}$ & + & 0.5771 \\
\hline & & $\begin{array}{l}\text { Transformation degree of } \\
\text { residential land use }\end{array}$ & Rural residential area/Total area of construction land & + & 0.1261 \\
\hline & & Tillage aggregation ratio & Cultivated land area /Rural residential area & - & 0.2968 \\
\hline
\end{tabular}


been widely used in the field of social and economic research. Its value reflects the degree of order of the system. The larger the entropy is, the more disorder the system is, the less information it carries, the smaller the variation degree of the index and the weight will be smaller; the lower the entropy is, the opposite(OU et al.2008; HE et al.2016). Calculation steps are as follows:

There are $n$ samples, each sample has $m$ evaluation indexes to construct the original matrix:

$Y=\left\{y_{i j}\right\}_{n \times m}(0<i \leq n, 0<j \leq m)$

is the standardized value of the $j$ item indicator in $i$ the county territory, and the proportion of the $j$ item index in the $i$ county territory is as follows:

$$
p_{i j}=\mathrm{y}_{i j} / \sum^{\mathrm{n}} \mathrm{y}_{i j}
$$

The entropy of item $j$ is:

$e_{j}=-k \sum_{i=1}^{\mathrm{n}} p_{i j} \ln p_{i j}$

Among them $k=1 / \ln n$, the coefficient of difference of item $j$ is expressed as follows: $g_{j}=1-e_{j}$, The larger the $g_{i}$ is, the more important the indicator $j$ is, and the weight of the final indicator is expressed as:

$$
w_{j}=g_{j} / \sum g_{j}
$$

The calculated weight of each index is shown in Table 1. In addition, the essence of rural hollowing is a bad evolutionary process caused by "empty houses for people" and "building the new without demolishing the old " in the process of urban-rural transformation and development (LIU et al.2009). Theoretically, the level of economic development determines the ability of different regions to absorb non-agricultural employment of the rural population, and the non-agricultural transfer of rural population is the direct reason for the loss of rural elements and formation of rural hollowing. And finally it showed the specific rural residential areas extensive degree of land use. From this perspective, economic development is the inducement; population transfer is the phenomenon and extensive use of rural land is the final result. Three factors together lead to the rural hollowing. Therefore, based on the above analysis and existing studies (TAN et al.2017; LU et al.2013; YANG et al.2012; LI et al.2014), the weight of the three subsystems of economy, population and land is assigned to 0.3333 .

\section{(3) Calculation of rural hollowing index}

Combined with the standardized values of the indicators and the weights of the indicators in Table 1 and the evaluation values of the three subsystems of economy, population and land, the hollowing index is calculated to characterize the degree of county rural hollowing in Henan province. The formula is as follows:

$$
H_{i}=\sum_{i=1}^{n} y_{i j} \times w_{i j}
$$

In the formula: $H_{i}$ is the rural hollowing index in region $i$, and the larger of $H_{i}$ values indicate the higher of the rural hollowing degree $y_{i j}$ is the standardized value of the $\mathrm{jth}$ indicator in region $\mathrm{i}, w_{i j}$ is the weight of the jth indicator.

\section{Spatial autocorrelation analysis}

(1) Global spatial autocorrelation

The global spatial autocorrelation is a description of the whole spatial distribution of the studied region, which expresses the spatial correlation and spatial difference characteristics of the study region. It is commonly expressed by the global Moran's I index, and the formula is (FENG et al.2014):

$$
I=\frac{n \sum_{i} \sum_{j} W_{i j}\left(x_{i}-\bar{x}\right)\left(x_{j}-\bar{x}\right)}{\left(\sum_{i} \sum_{j} W_{i j}\right) \sum_{i}\left(x_{i}-\bar{x}\right)^{2}}
$$

In the formula: $I$ is the global Moran index, $n$ is the number of the counties, $W_{i j}$ is the Spatial weight matrix, $x_{i}$ is the value of sample attribute, $\bar{x}$ is the sample mean, $\mathrm{i} \neq \mathrm{j}$. This paper uses the "post" adjacency definition weight matrix, Moran's I coefficient ranges from -1 to 1 . A negative Moran's I coefficient represents that there is a negative spatial correlation in the study area, a positive Moran's I coefficient represents that there is a positive spatial correlation in the study area, Moran's I coefficient is 0 represents that there is no spatial correlation in the study area.

\section{(2) Local spatial autocorrelation}

Local spatial autocorrelation is used to describe the spatial similarity and dissimilarity between the research units and adjacent units. It is expressed by the local Moran's I index. and the formula is:

$L=\frac{\left(x_{i}-\bar{x}\right)}{s^{2}} \sum_{j} W_{i j}\left(x_{j}-\bar{x}\right)$

In the formula: $L$ Represents the local Moran index, is the standard deviation of the sample values. This paper uses the local Moran index to generate a significant $(\mathrm{P}<0.05)$ spatial autocorrelation of county agglomeration maps in Open Geoda. 
Among them, $\mathrm{H}-\mathrm{H}$ agglomeration indicated that the high degree hollowing counties are surrounded by the high degree hollowing counties, L-L agglomeration indicated that the low degree hollowing counties are surrounded by the low degree hollowing of counties, and $\mathrm{H}-\mathrm{L}$ (L-H) agglomeration indicated that the high (low) degree hollowing counties are surrounded by the low (high) degree hollowing counties.

\section{Geo detector}

Geo detector is one of the methods used in spatial data exploration. This method was put forward by WANG et al. (2010) combined with spatial superposition technique and set theory. Its principle is to test the consistency of the two spatial distributions of attribute spatial differentiation and factor spatial differentiation. Initially, it was used to detect the relationship between environmental factors and human health (WANG et al. 2010; CAO et al. 2013). Later, LIU et al. used it to detect the impact of various factors on the spatial pattern of urbanization in China's counties (LIU et al. 2012), the differentiation mechanism of rural poverty (LIU et al. 2017), the pattern of village distribution (YANG et al. 2016) and other aspects. Compared with traditional analysis methods which the analysis function of spatial differentiation is weak, such as correlation coefficient, multiple regression analysis, production function, grey correlation analysis etc, the geo detector model not only has the ability to detect the different effects and the interrelationships of multiple factors under different spatial units, but also is suitable for a wide range of data types. Both the quantitative data and the nominal data can be used as explanatory variables of the geo detector model and the geo detector model is immune to data conjugated linear (WANG et al. 2017). Therefore, this study measured and analyzed the influence factors of spatial and temporal evolution of county rural hollowness in Henan province by using the method of geographical detector. Its model is as follows:
$P_{D, U}=1-\frac{1}{n \sigma_{U}^{2}} \sum_{i=1}^{m} n_{D, i} \sigma_{U D, i}^{2}$

In the formula: $D$ is the influencing factor, $U$ is the affected index, $P_{D, U}$ is the effect of $D$ on $U$ , and the larger $P_{D, U}$ is, the more it can influence the region, $n$ and $\sigma^{2}$ are the number and variance of the samples, respectively, $m$ is the classification number of an index, and $n_{D, i}$ is the sample number of $D$ in type $i$.Within the range of values from 0 to 1 .

\section{RESULTS AND ANALYSIS}

\section{Temporal evolution characteristics of rural hollowing} Variation characteristics of the hollowing index

According to the comprehensive measurement index system of county rural hollowness in Henan province, the hollowing index of 109 county units in Henan province from 2000 to 2013 was calculated. Then the frequency distribution of rural hollowness index was used to characterize the temporal variation of rural hollowness in Henan province (Table 2). It can be seen that, from 2000 to 2013, the county hollowing index in Henan province between 0.2136 and 0.7752 , and the range constantly increased from 0.4049 in 2000 to 0.5616 in 2010 and then decreased to 0.4166 in 2013 . The gap of rural hollowing among counties widens first and then decreased .As a whole, the average index of county hollowness from 2000 to 2013 is between 0.4181 and 0.5073 , it means that the hollowing of rural areas in county in the whole province is in the middle level. To be specific, the average index showed a decrement - increment - decrement change, that is, the level of rural hollowing in the county showed a decreasing trend from 2000 to 2005, an increasing trend from 2005 to 2010 and a distinctly decreasing trend after 2010 .

From the internal changes of the data, the standard deviation increases first, then decreased and

Table 2 - Variation characteristics of county rural hollowing index in Henan province.

\begin{tabular}{lccccccc}
\hline Year & Maximum value & Minimum value & Range & Average value & Standard deviation & Kurtosis coefficient & Skewness coefficient \\
\hline 2000 & 0.6949 & 0.2900 & 0.4049 & 0.4446 & 0.0769 & 1.0800 & 0.7950 \\
2005 & 0.6628 & 0.2408 & 0.4221 & 0.4181 & 0.0818 & 0.1848 \\
2010 & 0.7752 & 0.2136 & 0.5616 & 0.5073 & 0.0782 & 1.9033 & 0.4475 \\
2013 & 0.7021 & 0.2855 & 0.4166 & 0.4390 & 0.0889 & 0.1003 & 0.6784 \\
\hline
\end{tabular}


then increased, the values are all under 0.089 , indicated that the dispersion degree of county rural hollowing index and mean value in Henan province is small and in the trend of wave-like change, and the gap between the samples is not large as a whole. The kurtosis coefficients of the four years are $1.0800,0.1848$, 1.9033 and 0.1003 and the skewness coefficients are greater than 0 , indicating that the sample data exhibits a peak distribution and shifts to the right. The overall distribution of the data is concentrated, and the morphological changes were steep-smooth-Skewness coefficient constantly decreased between 2000 and 2010. It increased between 2010 and 2013, indicating that the number of highly hollowing counties is from more to less and then increased.

\section{Variation characteristics of hollowing degree}

In this study, natural breakpoint method in ArcGIS software was used to classify the degree of rural hollowing index in Henan province. Natural breakpoint method (JENKS,1967) is a natural clustering method that uses statistical formulas to determine attribute values in order to reduce the mean discrete variance within groups and increase the mean discrete variance between groups based on the inherent natural grouping of data. According to the distribution law of data, this method classified places where the data is discontinuous as the basis of classification, which can avoid the interference of human factors and widely use. (YANG et al. 2012; LIU et al. 2017; FAN et al. 2016). Therefore, the rural hollowing index of county units in Henan province from 2000 to 2013 is divided into five levels by using the natural breakpoint method, corresponding to five hollowing degrees respectively. Results were as follows: low degree hollowing $(<0.3526)$, lower degree hollowing (0.3527 0.4138), moderate hollowing (0.4139 0.4815), higher degree hollowing (0.4816 0.5656) and high degree hollowing $(>0.5656)$.
Table 3 shows changes in the number of counties with different degrees hollowing in different years. According to the distribution of hollowing types in each year, the proportion of moderate hollowing is always about $30 \%$, the number of counties is between 32 and 39, which is relatively large and the number is stable, while the number of the other four types counties showed obvious changes. From the perspective of time trend, there were significant differences in the changes of hollowing types in different periods. From 2000 to 2005, the rural hollowing at county level in Henan province changed from medium (moderate hollowing) and high grade (higher degree hollowing and high degree hollowing) to low grade (lower degree hollowing and low degree hollowing), the overall degree of hollowing of the province has declined in 2005. From 2005 to 2010 , the number of counties with medium grade hollowing remained unchanged, while the low grade hollowing migrated to the high grade hollowing on a large scale, resulting in the deterioration of hollowing situation in the whole province in 2010. From 2010 to 2013, the trend of change was reversed again, the high grade hollowing migrated to the low grade hollowing on a large scale, the number of medium grade hollowing remained basically unchanged, and the hollowing situation of the whole province was improved in 2013.

From the whole research period, the county hollowing in Henan province is polarized to both sides, the number of lower degree hollowing, moderate hollowing and higher degree hollowing decreases, while the number of low degree hollowing and high degree hollowing increases at the same time. Among them, the number of counties with low hollowing increased by 8 , higher than that of high hollowness by 3 . The county rural hollowing in the whole research period showed a stable and positive development trend in Henan province.

Table 3 - Variation characteristics of county rural hollowing degree in Henan province.

\begin{tabular}{|c|c|c|c|c|c|c|c|c|c|c|c|c|}
\hline \multirow[t]{2}{*}{ Type } & \multicolumn{2}{|c|}{-----------2000--------- } & \multicolumn{2}{|c|}{------------2005-------- } & \multicolumn{2}{|c|}{-----------2010---------- } & \multicolumn{2}{|c|}{-----------2013--------- } & \multicolumn{4}{|c|}{---------Number variation-------- } \\
\hline & Number & $\begin{array}{c}\text { Percentage } \\
(\%)\end{array}$ & Number & $\begin{array}{c}\text { Percentage } \\
(\%)\end{array}$ & Number & $\begin{array}{c}\text { Percentage } \\
(\%)\end{array}$ & Number & $\begin{array}{c}\text { Percentage } \\
(\%)\end{array}$ & $00-05$ & $05-10$ & $10-13$ & $00-13$ \\
\hline Low degree & 11 & 10.09 & 23 & 21.10 & 1 & 0.92 & 19 & 17.43 & 12 & -22 & 18 & 8 \\
\hline Lower degree & 31 & 28.44 & 34 & 31.19 & 8 & 7.34 & 28 & 25.69 & 3 & -26 & 20 & -3 \\
\hline Moderate & 39 & 35.78 & 32 & 29.36 & 32 & 29.36 & 35 & 32.11 & -7 & 0 & 3 & -4 \\
\hline Higher degree & 21 & 19.27 & 17 & 15.60 & 47 & 43.12 & 17 & 15.6 & -4 & 30 & -30 & -4 \\
\hline High degree & 7 & 6.42 & 3 & 2.75 & 21 & 19.3 & 10 & 9.17 & -4 & 18 & -11 & 3 \\
\hline
\end{tabular}

Ciência Rural, v.49, n.4, 2019. 
Spatial evolution characteristics of rural hollowing Spatial distribution characteristics

According to the results of grading degree of rural hollowing, the spatial distribution of county rural hollowing types in Henan province from 2000 to 2013 was mapped (Figure 2). In general, the level of county rural hollowing in Henan province is higher in northwest-southeast direction and lower in northeast-southwest direction. Further analysis reported that the distribution of the high degree rural hollowing in Henan province gradually changed from fragmentation to agglomeration, focusing on two regions: (1) Taking the western counties of Zhengzhou as the nodes, including the front line of the northwest of Henan of the northern of Luoyang city, northeastern of Sanmenxia city, southwestern of Jiaozuo city and Jiyuan city, Xinxiang city and some counties of Anyang city; (2) Eastern of Xinyang city. Layout of the higher degree hollowing area is relatively scattered, which is mainly surrounding or adjacent to the high degree hollowing area, gradually transferring from west and south of Henan to east and north of Henan, and Nanyang city in the southwestern of Henan, Pingdingshan city in the central region of Henan and Xuchang city gradually disappeared. New areas of Kaifeng city in the east of Henan, Shangqiu city and northeastern Zhoukou city were added. The layout of the moderately hollowing area changed from concentrated to disperse and its spatial configuration changed from circular agglomeration to "U" type distribution and finally distributed along the provincial boundary and some county areas in the middle of Henan province into a "W"-shaped strip. The change of the lower degree hollowing area showed a process of convergence from the periphery to the center and gradually concentrates on the western part of Luoyang, the majority of Pingdingshan city, the southern part of Xuchang city, the northern part of Zhumadian city, the western part of Zhoukou city, while the part of north and east of Henan gradually disappeared. The low degree hollowing area is mainly characterized by a smallscale agglomeration that continuously moves to north regions. The gathering center is gradually transferred

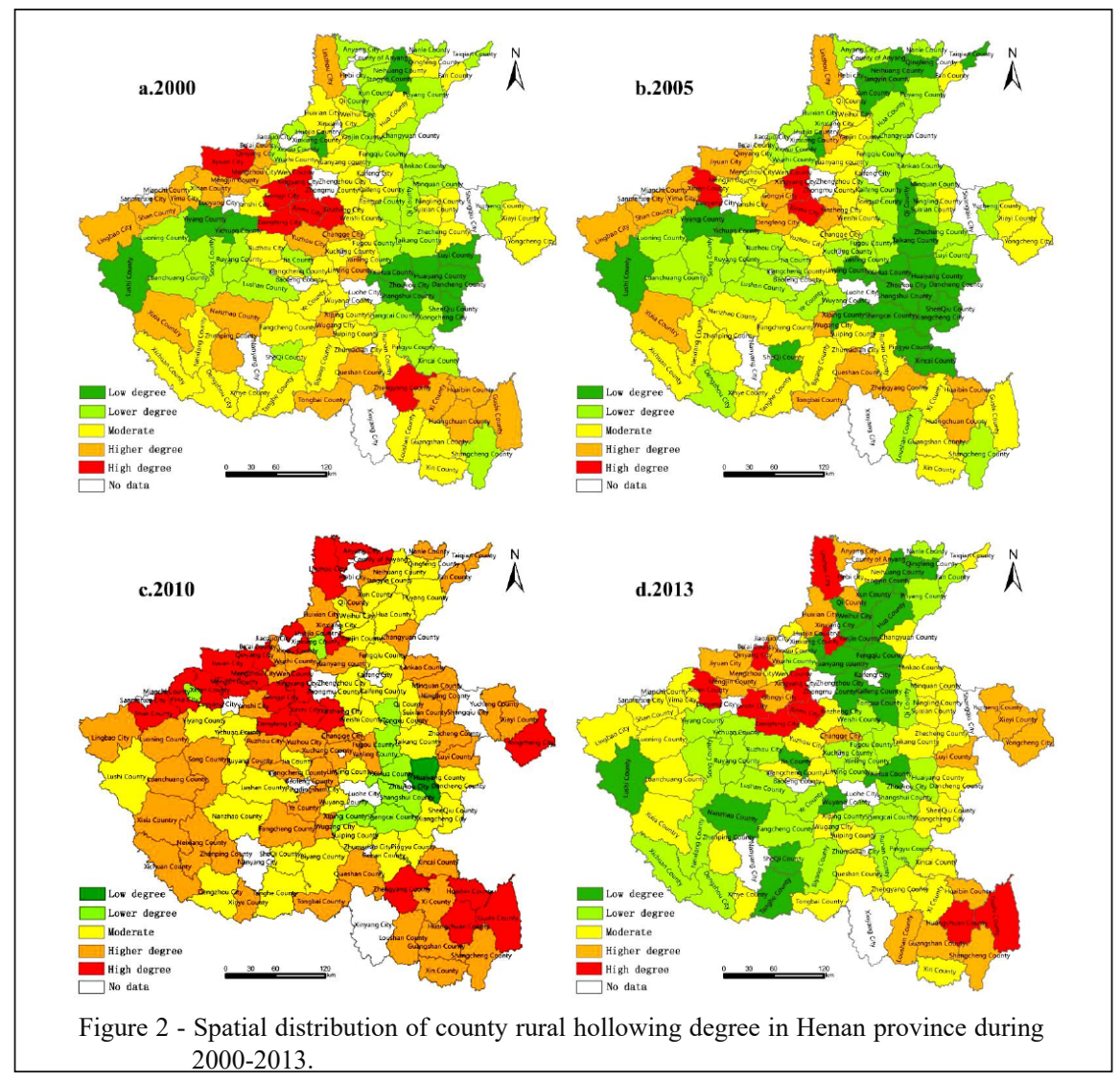

Ciência Rural, v.49, n.4, 2019. 
from the Zhoukou city to the Xinxiang city, Hebi city and Anyang city intersections in the north of Henan, and there are also sporadic distributions in the middle and southwest of Henan.

\section{Spatial association characteristics}

(1)Global Moran's I. It can be seen from Table 4 that the $p$-values of all four years are less than 0.01 , and the Moran's I index is positive, indicating that there is an extremely significant and positive spatial correlation of rural hollowing in Henan province, it shows that there are obvious spatial agglomeration characteristics of rural hollowing in each county of Henan province during the study period. From the perspective of time change, the Moran's I index showed a fluctuating trend and decreases slightly as a whole, which is consistent with the temporal change of the provincial rural hollowing index. It showed that, from 2000 to 2013 , the degree of county rural hollowing agglomeration in Henan province decreased at first, then increased and then decreased. The overall aggregation is slightly weakened.

(2) Local Moran's I. Using Open Geoda software,a LISA map of the level of county rural hollowing in Henan province with significant $(\mathrm{P}<0.05)$ spatial autocorrelation (Figure 3) was generated. From 2000 to 2013, the characteristics of county scale rural hollowing agglomeration in Henan province are obvious, involving three types of $\mathrm{H}-\mathrm{H}, \mathrm{H}-\mathrm{L}$ and L-L agglomeration, mainly focus on the types of H-H and L-L. Number of counties in the $\mathrm{H}-\mathrm{H}$ and $\mathrm{L}-\mathrm{L}$ agglomeration area is large and the agglomeration characteristics are obvious, while the H-L agglomeration area is from scratch and the number of counties is small and scattered.

Spatial pattern of the $\mathrm{H}-\mathrm{H}$ agglomeration area is relatively stable with local changes and the number of counties constantly increase, among which the stable regional distribution is contiguous, mainly including Jiyuan, Mengjin, Mengzhou, Wen county, Yanshi, Yuzhou and all the counties in Zhengzhou except Zhongmou. These counties are adjacent to the major core cities of Henan province, have a high level of economic and social development, a high

Table 4 - Global Moran's I of county rural hollowing in Henan province.

\begin{tabular}{lcccc}
\hline Year & 2000 & 2005 & 2010 & 2013 \\
\hline Moran's I & 0.4567 & 0.4331 & 0.4863 & 0.4479 \\
P-value & 0.001 & 0.001 & 0.001 & 0.001 \\
Z-score & 7.2879 & 6.6826 & 7.4801 & 6.7372 \\
\hline
\end{tabular}

level of urbanization in the province, a relatively high proportion of non-agricultural industries, the large proportion of rural population in non-agricultural employment and the frequent transfer to cities and towns, all these reasons led to a higher level of rural hollowing. The variability region is from scratch and finally gathers in the eastern part of Xinyang. This area is located in the key radiation areas of Wuhan metropolitan area and Hefei metropolitan area. Because of their own low level of economic development and the siphon effect of the surrounding economic highlands, a large number of rural populations are transferred to urban areas. At the same time, due to locate in the Dabie Mountains, the population density is low and the extensive utilization of rural residential land is serious, resulting in a higher degree rural hollowing.

Spatial pattern of the L-L agglomeration area is in a dynamic change and gradually moving from southern to northern, and the key area of agglomeration is gradually transferred from Zhoukou to Qi county, Tongxu, Kaifeng County which are all belong to Kaifeng city and the middle and lower reaches of Yellow River beach area in North Henanprovince. The number of counties showed an inverted " $U$ " shaped change trend, reaching the highest in 2005. Among them, the urbanization level of Zhoukou area was on the low side in the past, the degree of effective transfer of rural population was low and the phenomenon of rural hollowing was not prominent. In recent years, with the in-depth promotion of undertake industrial transfer in Henanprovince, Zhoukou has become an important position for attracting investment. Industrialization has promoted the vigorous development of urbanization and effectively promoted the transfer of rural population employment so that the phenomenon of hollowing in rural areas is becoming increasingly serious. The middle and lower reaches of Yellow River Beach area in northern Henan province is a national contiguous destitute area and a key county concentration area for poverty alleviation and development. It is restricted by special location conditions with high incidence of poverty. The proportion of the primary industry is large, the level of urbanization is lagging behind, the rural non-agricultural economy is underdeveloped, the non-agricultural employment of the rural population is low, at the same time, because the income level of farmers here is low, the phenomenon of homestead expansion is not obvious and the degree rural hollowing is generally low.

\section{Analysis on the influencing factors of rural hollowing}

The formation and evolution of rural hollowing are closely related to natural conditions, rural population, social economy, land management 


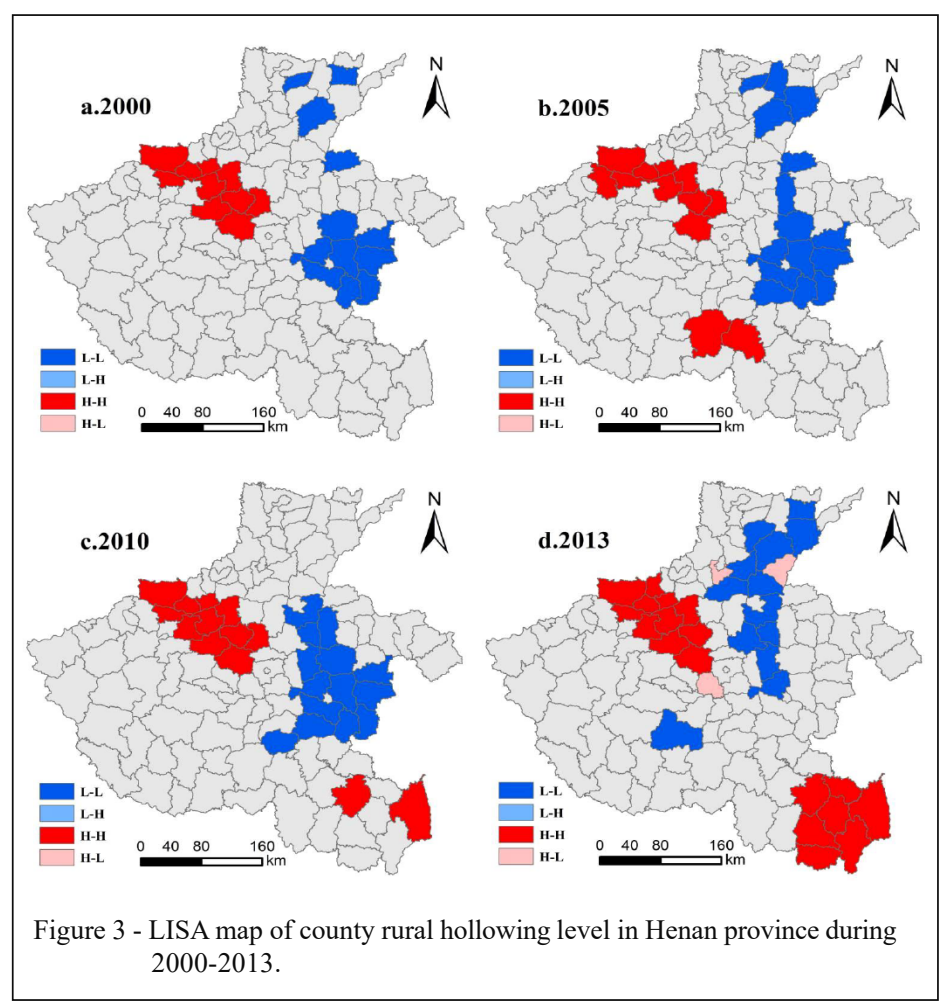

and other factors (LONG et al. 2009; QIAO et al. 2011). Henan province is located in the North China Plain. The natural factors such as location, topography and geomorphology have little or relatively constant effect on the evolution of rural hollowing in the short term. However, the drastic changes of the rural population, social economy, land management and other factors in the context of rapid urbanization and new rural construction in recent years are the main reasons for the evolution of rural hollowness in Henan province. Thus, based on the above analysis and related studies (TAN et al.2017; SONG et al. 2013; QIAO et al. 2011; YUAN et al. 2015), this study combined with the actual situation and data availability in Henan province, according to the principles of science, comprehensiveness and objectivity,. Fourteen indexes are selected as the influencing factors of rural hollowing (Table 5), and then the influence of each factor on the hollowing of counties and villages in Henan province is analyzed and compared. Among them, Permanent rural population, Rural population density and Proportion of agricultural employed population represent the hollowing effect of rural population factors and GDP. Proportion of secondary and tertiary industry, Per capita net income of farmers, average land fiscal revenue, Investment in fixed assets, urbanization rate, savings balance of urban and rural residents represent the hollowing effect of social and economic factors; arable land area per capita, land area average grain yield, land reclamation rate and per capita homestead area represent the hollowing effect of land management factors.

\section{Leading factors in rural hollowing}

The geo detector method requires that the independent variables must be type quantity. Therefore, the value of each influencing factor is divided into five levels by using the natural breakpoint method. Furthermore, the influence of different factors on rural hollowing in Henan province was calculated by using geo detector method and the effect of different factors on rural hollowing was calculated (Table 5).

The analysis showed that there are five factors which have a weak effect on hollowing during the study period, including permanent rural population, rural population density, arable land area per capita, land area average grain yield, savings balance of urban and rural residents, being the influence of these factors relatively small. The proportion of agricultural employed population, GDP, 
Table 5 - The results of geo detector of the influencing factors of rural hollowing.

\begin{tabular}{|c|c|c|c|c|c|c|c|c|}
\hline \multirow[t]{2}{*}{ Influencing factor } & \multicolumn{2}{|c|}{------------2000----------- } & \multicolumn{2}{|c|}{------------2005----------- } & \multicolumn{2}{|c|}{------------2010---------- } & \multicolumn{2}{|c|}{------------2013------------- } \\
\hline & $P_{D, U}$ value & Sequence & $P_{D, U}$ value & Sequence & $P_{D, U}$ value & Sequence & $P_{D, U}$ value & Sequence \\
\hline Permanent rural population & 0.089 & 14 & 0.108 & 13 & 0.108 & 12 & 0.082 & 13 \\
\hline Rural population density & 0.092 & 13 & 0.183 & 8 & 0.148 & 10 & 0.114 & 11 \\
\hline $\begin{array}{l}\text { Proportion of agricultural } \\
\text { employed population }\end{array}$ & 0.290 & 2 & 0.096 & 14 & 0.256 & 7 & 0.263 & 6 \\
\hline GDP & 0.270 & 3 & 0.167 & 9 & 0.313 & 4 & 0.231 & 7 \\
\hline $\begin{array}{l}\text { Proportion of secondary and } \\
\text { tertiary industry }\end{array}$ & 0.415 & 1 & 0.260 & 4 & 0.356 & 3 & 0.309 & 3 \\
\hline Per capita net income of farmers & 0.224 & 4 & 0.187 & 7 & 0.295 & 5 & 0.304 & 4 \\
\hline Average land fiscal revenue & 0.175 & 8 & 0.247 & 5 & 0.249 & 8 & 0.115 & 10 \\
\hline Investment in fixed assets & 0.218 & 5 & 0.274 & 3 & 0.406 & 1 & 0.267 & 5 \\
\hline Urbanization rate & 0.196 & 7 & 0.197 & 6 & 0.109 & 11 & 0.359 & 2 \\
\hline $\begin{array}{l}\text { Savings balance of urban and } \\
\text { rural residents }\end{array}$ & 0.112 & 10 & 0.127 & 11 & 0.105 & 13 & 0.206 & 8 \\
\hline Arable land area per capita & 0.109 & 11 & 0.109 & 12 & 0.041 & 14 & 0.110 & 12 \\
\hline Land area average grain yield & 0.103 & 12 & 0.161 & 10 & 0.160 & 9 & 0.061 & 14 \\
\hline Land reclamation rate & 0.173 & 9 & 0.281 & 2 & 0.277 & 6 & 0.191 & 9 \\
\hline Per capita homestead area & 0.215 & 6 & 0.338 & 1 & 0.367 & 2 & 0.479 & 1 \\
\hline
\end{tabular}

agricultural employed population, urbanization rate and land reclamation rate are five factors that affect hollowing in the middle level. While the influential factors that have a strong influence on hollowing are the per capita homestead area, the proportion of secondary and tertiary industries, the investment in fixed assets and the per capita net income of farmers, and their influence is always at the top of the list.

Combined with the results of the geo detector at different time cross-sections, the per capita homestead area, the proportion of secondary and tertiary industries, the investment in fixed assets, and the per capita net income of farmers were taken as the dominant factors in the spatio-temporal evolution of rural hollowing in Henan province during the study period.

\section{Influence mechanism of rural hollowing}

The dominant factors influencing the spatio-temporal evolution of rural hollowing in Henan province were determined by geo detector, and their influence mechanism of each dominant factor on hollowing was further analyzed.

(1)Percapita homestead area. During the study period, the influence of per capita homestead area on hollowing constantly increase from 0.215 in 2000 to 0.479 in 2013, which became the most influential factor. From 2000 to 2013, the per capita homestead area in Henan province increased by $115.25 \mathrm{~m} 2$, among which the per capita homestead area of Huangchuan, Yanshi, Luoshan, Gushi, Shangcheng, and Xiangyang increased over 230m2, the average value of rural cavitation index increased by 0.133 . In addition, compared with the spatial variation characteristics of hollowing index and per capita homestead area in different years, it is reported that the two have strong consistency in spatial variation. The larger the per capita homestead area is, the larger the rural vacant homestead area is and the phenomenon of multi-family and over-standard area in one household in rural areas will be more serious, which leads to a higher degree rural hollowing. Therefore, the per capita homestead area is one of the key factors that lead to the hollowing of rural areas.

(2) Proportion of secondary and tertiary industries. At four time cross sections in 2000, 2005, 2010 and 2013, the influence of the proportion of secondary and tertiary industries on hollowing is $0.415,0.260,0.356$ and 0.309 , respectively, which shows a weakening trend but its influence is still relatively strong. In 2013, for example, the counties of Xinmi, Yanshi, Qinyang, Linzhou, Dengfeng, Xingyang, Xin'an, and Xinxiang with developed secondary and tertiary industries (proportion for more than 93\%) attract a large number of rural laborers moving to cities and towns with dense secondary and tertiary industries. This has aggravated the phenomenon of "people leaving making empty houses" caused by the nonagricultural transformation of the rural population, 
thus resulting in a high degree of hollowing in these areas. On the contrary, in the counties of Xihua, Hua county, Fengqiu, and Neihuang where the proportion of secondary and tertiary industries is backward (proportion for less than $68 \%$ ), the degree of hollowing is very low. Therefore, the proportion of secondary and tertiary industries is still one of the important factors affecting hollowing.

(3) Investment in fixed assets. In 2000, 2005, 2010 and 2013, the influence of fixed asset investment on hollowing was $0.218,0.274,0.406$ and 0.267 , respectively, showing the characteristics of inverted "U" pattern. The investment in fixed assets in Henan province increased by 266.52 billion yuan from 2000 to $2005,902.26407$ billion yuan from 2005 to 2010 and 608.71799 billion yuan respectively from 2010 to 2013. It also showed an inverted "U" type change. Among them, the growth was relatively rapid from 2005 to 2010 , at this time, the impact on hollowing is also the strongest. After 2010, the growth rate slowed down slightly, but the scale of investment continued to increase, which led to a decrease in the influence of this factor on hollowing after 2010. But the effect is still relatively strong.

Comparing the investment in fixed assets and the rural hollowing index of various counties in different time sections, it is reported that the rural hollowing index is also relatively low in the areas with lower fixed asset investment such as Taiqian, Huojia, Xiping, while,e the rural hollowing index is also relatively high in areas with higher investment in fixed assets, such as Linzhou, Xinmi, and Xingyang. The reason is that the county with a large fixed asset investment has a relatively high level of urban infrastructure and the ability of towns attracting rural farmers is relatively strong, so the degree of rural hollowing is relatively high. On the contrary, the degree of hollowing is relatively low.

(4) Per capita net income of farmers. The influence of per capita net income of farmers on hollowing was $0.224,0.187,0.295$ and 0.304 in 2000, 2005, 2010 and 2013, respectively, showing the characteristics of "U" type change, which indicates that the influence of per capita net income of farmers on rural hollowing was relatively weak in 2000 and 2005 respectively. However, with the rapid development of rural economy, the abolition of agricultural tax after 2005 and a series of agricultural policies introduced, the level of farmers' income has increased by a large margin. In 2013, the per capita net income of farmers in the province was three times that of 2005. Increase of farmers' income has enhanced the farmers' ability and willingness to build houses. Because of the beautiful environment outside the village and convenient transportation, wealthy farmers will choose to reapply for homestead and build new houses and old houses cannot effectively quit because of the high cost of demolition, which directly caused that people are willing to build new rural residential areas without demolishing old ones so that one household has many houses and the rural hollowing developed quickly. In addition, the per capita net income of farmers in the eastern part of Xinyang city is relatively low and the attraction of high urban incomes has caused many farmers to bring along their families to work outside all year round. However, because of the restrictions on household registration and land property rights, many migrant workers are unwilling to abandon their unused houses in the villages. This has contributed to the degree of hollowing in the region to a certain extent.

\section{DISCUSSION}

Taking Henan province as an example, which has a typical rural hollowing problem, this paper constructs the evaluation index system of rural hollowing from the aspects of economy, population and land, and then uses entropy weight method, hollowing index method and spatial autocorrelation analysis and other methods to analyze the spatial and temporal evolution characteristics of rural hollowing in Henan province. Combined with the geo detector method, the main factors affecting the evolution of rural hollowing and its mechanism are identified. This provides an empirical basis to identify the evolution process of rural hollowing in county area of Henan province from two dimensions of space-time and explore the driving force of rural hollowing evolution. In addition, based on the county scale, this study reveals the spatial-temporal variation characteristics and influencing factors of rural hollowing in the meso-scale provincial scope, which is also the deepening and improvement of the related research results at the provincial level. At the same time, it can provide scientific basis for macro-decision-making of rural hollowing in provincial area.

The phenomenon of rural hollowing has certain universality, developed countries and regions have had similar problems. As the largest agricultural and populous province in China, the emergence of rural hollowing in Henan has certain inevitability. According to the research, the rural hollowing in Henan province from 2000 to 2013 was at a medium level as a whole, which is consistent with the results of YANG et al. (2012) that the regional types of 
rural hollowing in China based on county scale are divided into the mid-value regions of stable economic development in the Huang HuaiHai Plain. Similar to the related research results, this study considered that per capita homestead area, investment in fixed assets and per capita net income of farmers are the leading factors driving the evolution of rural hollowing in Henan province. For example, based on the background of rapid urbanization,TAN et al. (2017) believe that per capita homestead area, investment in fixed assets and per capita net income of farmers have a significant impact on rural hollowing in changzhutan area. WANG et al. (2013) believed that the factors such as the number of homestead per family and the per capita income of villages drive the evolution of rural hollowing in Shandong province. It should be noted that development of secondary and tertiary industries also play an important role in the evolution of hollowing rural in Henan province, while it has not been well reflected in other studies. It can be explained from the following two aspects: (1) The difference of subject background, research scale and research topic will lead to different influencing factors of rural hollowing put forward by researchers; (2) Economic development is usually the primary driving factor of land-use change (LONG et al. 2009).

Henan province is a traditional agricultural province and agricultural production plays an important role in the social economy of Henan province. Therefore, the hollowing effect brought by the increasing proportion of secondary and tertiary industries, which is inevitable with the development of economy, is more significant in this big agricultural province.

In addition, statistical analysis, system analysis and modeling methods are mainly used in the traditional analysis of driving forces of influencing factors (TAN et al. 2017; WANG et al. 2013; DUAN et al. 2004; SHU et al. 2014). There are many data requirements and assumptions in these calculation models, such as normality and homogeneity, et al. However, the geographical objects in reality cannot completely meet these requirements, so that the effect of its mathematical model is limited. Geo detector model is a new spatial analysis model to evaluate the relationship between geographical objects and its influence factors. This study introduces geo detector into the quantitative study of the driving force of rural hollowing evolution, which has the following advantages: (1) The model has almost no hypothetical condition, which overcomes the limitation of the traditional computing model in facing similar problems.(2) It can quantitatively analyze the relative importance of the influencing factors that lead to the evolution of rural hollowing.
(3) There is no need to consider the problem about collinearity of independent variables and the model can guarantee that it is immune to multi-independent variables collinearity. Therefore, the introduction of geographical detector model in this study can ensure the reliability of the research results.

It should also be noted that the factors affecting the evolution of rural hollowing are complex. In addition to the factors stated in this study, the phased changes in the system and management policies are also important factors causing the changes in rural residential land use (LIU et al.2010; LONG et al.2009). However, in the study of the mechanism of quantitative identification of influencing factors (TAN et al.2017; YUAN et al.2015; WANG et al.2015), it is often ignored because it's very hard to quantify. Therefore, how to quantify these factors and make them comparable with other factors is the focus of future research. In addition, in reality, the main factors of rural hollowing among counties in Henan province are different due to the large gap in the level of social and economic development as well as the way and efficiency of land use in different counties. So the influence factors and mechanism of hollowing on county scale in Henan province need to be further deepened and refined.

\section{CONCLUSION}

The gap of rural hollowing between counties in Henan was expand first and then decrease from 2000 to 2013, and the whole province was at the middle level of rural hollowing. The county hollowing in Henan province was polarized to both sides, and Henan province county rural hollowing in the whole research period showed a stable and positive development trend. The level of county rural hollowing in Henan province was higher in northwestsoutheast direction and lower in northeast-southwest direction. The rural hollowing $\mathrm{H}-\mathrm{H}$ agglomeration area in Jiyuan, Mengjin, Mengzhou, Wen county, Yanshi and Yuzhou, Zhengzhou, eastern Xinyang in the upper reaches of Yellow River Beach, the L-L gathering area is gradually transferred from Zhoukou to Qi county, Tongxu, Kaifeng County which are all belong to Kaifeng city, and the middle and lower reaches of Yellow River beach area in North Henan province; the H-L gathering area is from scratch, with a small number and scattered distribution. Geo detector showed that the per capita housing area, the proportion of secondary and tertiary industries, the investment in fixed assets and the per capita net income of farmers are the dominant factors in rural hollowing.

Ciência Rural, v.49, n.4, 2019. 


\section{ACKNOWLEDGEMENTS}

This work was supported by National key research priorities program of China-Variation mechanism and trend prediction of water and sediment in the Yellow River Basin (2016YFC0402402), and the open project of Key laboratory of Soil and Water Loss Process and Control on the Loess Plateau of the Ministry of Water Resources-Simulation of Soil and Water Loss Process in Hill and Gully Region of the Loess Plateau Based on GIS (2016005).

\section{DECLARATION OF CONFLICTING INTERESTS}

The authors declare no conflict of interest. The founding sponsors had no role in the design of the study; in the collection, analyses, or interpretation of data; in the writing of the manuscript, and in the decision to publish the results.

\section{AUTHORS' CONTRIBUTIONS}

All authors contributed equally for the conception and writing of the manuscript. All authors critically revised the manuscript and approved of the final version.

\section{REFERENCES}

CAO, F. et al. Optimal discretization for geographical detectors-based risk assessment. GIScience \& Remote Sensing, v.50, n.1, p.78-92, 2013. Available from: <https://doi.org/10.1 080/15481603.2013.778562>. Accessed: Mar. 15, 2019. doi: $10.1080 / 15481603.2013 .778562$.

CHENG, L.S. et al. The Analysis of Rural Settlement Hollowizing System of the Southeast of Taiyuan Basin. Acta Geographica Sinica, v.56, n.4, p.437-446, 2001. Available from: <http://www. geog.com.cn/dls/CN/10.11821/xb200104007>. Accessed: Mar. 15, 2019. doi: $10.11821 / \mathrm{xb} 200104007$.

DUAN, Z.Q. et al. Construction of a Land-use Change Simulation Model and Its Application in Haidian District,Beijing. Acta Geographica Sinica, v.59, n.6, p.1037-1047, 2004. Available from: $<$ http://www.geog.com.cn/dls/CN/10.11821/xb200406028>. Accessed: Mar. 15, 2019. doi: 10.11821/xb200406028.

FAN, P.F. et al. Evaluation of coordinated development of urbanization from the perspective of system coupling in the Beijing-TianjinHebei Region. Resources Science, v.38, n.12, p.2361-2374, 2016. Available from: <http://www.wanfangdata.com.cn/details/detail. do? type=perio\&id=zykx201612015>. Accessed: Mar. 15, 2019. doi: $10.18402 /$ resci.2016.12.15

FENG, Z.X. et al. Spatial Cluster Analysis of Provincial Carbon Intensity in China. Resources Science, v.36, n.7, p.1462 1468, 2014. Available from: <http://www.cqvip.com/QK/9083 1A/201407/90829089504849524855484955.html>. Accessed: Mar. 15, 2019.

HE, Y.B. et al. Assessment and influencing factors of social vulnerability to rapid urbanization in urban fringe:A case study of Xi'an. Acta Geographica Sinica, v.71, n.8, p.1315-1328, 2016. Available from: <http://www.geog.com.cn/dls/CN/10.11821/ dlxb201608003>. Accessed: Mar. 15, 2019. doi: 10.11821/ dlxb201608003.
JENKS, G.F. The data model concept in statistical mapping. International Yearbook of Cartography, v.7, n.1, p.186-190, 1967.

JIAO, B.F. Analysis on the situation and characteristics in Japanese depopulation areas accompanying its rapid economic development. Chinese Rural Economy, v.8, p.73-79, 2004. Available from: <http://www.wanfangdata.com.cn/details/detail.do? type=p erio\&id=NSSD201403250000069996>. Accessed: Mar. 15, 2019.

LI, L. et al. The study of spatial characteristics and correlations for county region urbanization and rural hollowing in Mianyang city. Journal of Sichuan Normal University(Natural Science Edition), v.37, n.5, p.728-734, 2014. Available from: <http:// www.wanfangdata.com.cn/details/detail.do?_type $=$ perio\&id $=\mathrm{s}$ csfdxxb201405020>. Accessed: Mar. 15, 2019. doi: 10.3969/j. issn.1001-8395.2014.05.020.

LIU, Y.S. et al. Geographical research and optimizing practice of rural hollowing in China. Acta Geographica Sinica, v.64, n.10, p.1193-1202, 2009. Available from: <http://www.geog.com.cn/ dls/CN/10.11821/xb200910005>. Accessed: Mar. 15, 2019. doi: 10.3321/j.issn:0375-5444.2009.10.005.

LIU, Y.S. et al. Progress and Prospect on the Study of Rural Hollowing in China. Geographic Research, v.29, n.1, p.3542, 2010.Available from: <http://www.dlyj.ac.cn/CN/10.11821/ yj2010010004>. Accessed: Mar. 15, 2019. doi: 10.11821/ yj2010010004.

LIU, Y.S. Research on the urban-rural integration and rural revitalization in the new era in China. v.73, n.4, p.637-650, 2018. Available from: <http://www.geog.com.cn/dls/CN/10.11821/ dlxb201804004>. Accessed: Mar. 15, 2019. doi: 10.11821/ dlxb201804004.

LIU, Y.S. et al. The Spatial Characteristics and Formation Mechanism of the County Urbanization in China. Acta Geographica Sinica, v.67, n.8, p.1011-1020, 2012. Available from: <http://www. geog.com.cn/dls/CN/10.11821/xb201208001>. Accessed: Mar. 15, 2019. doi: $10.11821 / x b 201208001$.

LIU, Y.S. et al. Geographic detection and optimizing decision of the differentiation mechanism of rural poverty in China. Acta Geographica Sinica, v.72, n.1, p.161-173, 2017. Available from: $<$ http://www.geog.com.cn/dls/CN/10.11821/dlxb201701013>. Accessed: Mar. 15, 2019. doi: 10.11821/dlxb201701013.

LONG, H.L. Land consolidation and rural spatial restructuring. Acta Geographica Sinica, v.68, n.8, p.1019-1028, 2013. Available from: $\quad<$ http://www.geog.com.cn/dls/CN/Y2013/V68/I8/1019>. Accessed: Mar. 15, 2019.

LONG, H.L. et al. Analysis of Evolutive Characteristics and Their Driving Mechanism of Hollowing Villages in China. Acta Geographica Sinica, v.64, n.10, p.1203-1213, 2009. Available from: $<$ http://www.geog.com.cn/dls/CN/10.11821/xb200910006>. Accessed: Mar. 15, 2019. doi: DOI: 10.11821/xb200910006.

LU, S.S. et al. Rural Land Consolidation Potential of Typical Transect along No.106 State Road. Acta Geographica Sinica, v.28, n.4, p.537-549, 2013. Available from: <http://www.jnr.ac.cn/ CN/10.11849/zrzyxb.2013.04.001>. Accessed: Mar. 15, 2019. doi: 10.11849/zrzyxb.2013.04.001.

OU, X.J. et al. Study on compression level and ideal impetus of regional urbanization:The case of Jiangsu province. Geographi- 
cal Research, v.27, n.5, p.993-1002, 2008. Available from: <http:// www.dlyj.ac.cn/CN/10.11821/yj2008050003>. Accessed: Mar. 15, 2019. doi: $10.11821 / \mathrm{yj} 2008050003$.

PAN, J.H. et al. Measurement of Rural Hollowing and Inter-County Differences in Gansu. Population and Development, v.19, n.6, p.65-73, 2013. Available from: <http://www.wanfangdata.com.cn/ details/detail.do? type $=$ perio\&id $=$ scyrkfx201306009>. Accessed: Mar. 15, 2019. doi:10.3969/j.issn.1674-1668.2013.06.009.

QIAO, J.J. et al. Characteristics and Microcosmic Mechanism of Rural Hollow Villages in Less Developed Rural Area: A Case Study of Three Villages in Lankao County. Human Geography, v.26, n.6, p.98-102+160, 2011. Available from: $<$ http://rwdl.xisu. edu.cn/CN/10.13959/j.issn.1003-2398.2011.06.015>. Accessed: Mar. 15, 2019. doi: 10.13959/j.issn.1003-2398.2011.06.015.

SHU, B.R. et al. Spatial Heterogeneity of Driving Forces of Rural Residendential Land Evol-ution in Township of Developed Regions-A Case Stuy of Ludy and Liuhe in Taicang. Resources and Environment in the Yangtze Basin, v.23, n.6, p.759-766, 2014. Available from: <http://www.wanfangdata.com.cn/details/detail. do? type $=$ perio\&id $=67747689504849524854484851>$. Accessed: Mar. 15, 2019. doi: 10.11870/cjlyzyyhj201406003.

SONG, W. et al. Typical survey and analysis on influencing factors of village-hollowing of rural housing land in China. Geographical Research, v.32, n.1, p.20-28, 2013. Available from: <http:// www.dlyj.ac.cn/CN/10.11821/yj2013010003>. Accessed: Mar. 15, 2019. doi: $10.11821 / \mathrm{yj} 2013010003$

TAN, X.L. et al. Assessment and influencing factors of rural hollowing in the rapid urbanization region: A case study of Changsha-Zhuzhou-Xiangtan urban agglomeration. Geographical Research, v.36, n.4, p.684-694, 2017. Available from: <http://www. dlyj.ac.cn/CN/10.11821/dlyj201704007>. Accessed: Mar. 15, 2019. doi: $10.11821 /$ dlyj201704007.

TANG, C.L. et al. The research on optimization mode of spatial organization of rural settle-ments oriented by life quality. Acta Geographica Sinica, v.69, n.10, p.1459-1472, 2014. Available from: $<\mathrm{http}: / /$ www.geog.com.cn/dls/CN/10.11821/dlxb201410006>. Accessed: Mar. 15, 2019. doi: 10.11821/dlxb201410006.

TIAN, G.J. et al. Rural settlement land dynamic modes and policy implications in Beijing metropolitan region. China Habitat International, v.44, p.237-246, 2014. Available from: $<$ https://doi. org/10.1016/j.habitatint.2014.06.010>. Accessed: Mar. 15, 2019. doi: 10.1016/j.habitatint.2014.06.010.

WANG, G.G. et al. Evolution mechanism and regulation and strategies of hollowed villages in China. Research of Agricultural Modernization, v.36, n.1, p.34-40, 2015. Available from: <http:// dx.doi.org/10.13872/j.1000-0275.2014.0071>. Accessed: Mar. 15, 2019. doi: $10.13872 / \mathrm{j} .1000-0275.2014 .0071$.

WANG, J.F. et al. Geodetector:Principle and prospective. Acta Geographica Sinica, v.72, n.1, p.116-134, 2017. Available from: $<$ http://www.geog.com.cn/dls/CN/10.11821/dlxb201701010>. Accessed: Mar. 15, 2019. doi: 10.11821/dlxb201701010.

WANG, J.F. et al. Geographical detectors-based health risk assessment and its application in the neural tube defects study of the Heshun Region, China. International Journal of Geographical Information Science, v.24, n.1, p.107-127, 2010. Available from: $<$ https://doi.org/10.1080/13658810802443457>. Accessed: Mar. 15, 2019. doi: $10.1080 / 13658810802443457$.

WANG, J.Y. et al. Empirical analysis on influencing factors of the hollowing village degree:Based on the survey data of sample villages in Shandong province. Journal of Natural Resources, v.28, n.1, p.10-18, 2013. Available from: <http://www.jnr.ac.cn/ CN/Y2013/V28/I1/10>. Accessed: Mar. 15, 2019. doi: 10.11849/ zrzyxb.2013.01.002.

WHITE, E.M. et al. Past and projected rural land conversion in the US at state, regional, and national levels. Landscape Urban Plan, v.89, p.37-48, 2009. Available from: <https://doi.org/10.1016/j.landurbplan.2008.09.004>. Accessed: Mar. 15, 2019. doi: 10.1016/j. landurbplan.2008.09.004.

YANG, R. et al. Spatial Distribution Characteristics and Optimized Reconstructing Analysis of Rural Settlement in China. Scientia Geographica Sinica, v.36, n.2, p.170-179, 2016. Available from: <http://geoscien.neigae.ac.cn/CN/10.13249/j.cnki. sgs.2016.02.002>. Accessed: Mar. 15, 2019. doi: 10.13249/j.cnki. sgs.2016.02.002.

YANG, R. et al. Comprehensive measure and partition of rural hollowing in China. Geographic Research, v.31, n.9, p.16971706, 2012. Available from: <http://www.dlyj.ac.cn/CN/10.11821/ yj2012090015>. Accessed: Mar. 15, 2019. doi: 10.11821/ yj2012090015.

YU, Z.W. et al. Spatial restructuring and land consolidation of urban-rural settlement in mountainous areas based on ecological niche perspective. Journal of Geographical Sciences, v.28, n.2, p.131-151, 2018. Available from: $<$ https://doi.org/10.1007/s11442018-1464-2>. Accessed: Mar. 15, 2019. doi: 10.1007/s11442-0181464-2.

YUAN, Y. et al. A GWR-based study on Jincheng city hollow village driving force. Economic Geography, v.35, n.7, p.148-155, 2015. Available from: <http://www.wanfangdata.com.cn/details/ detail.do? type=perio\&id=665503290>. Accessed: Mar. 15, 2019. doi: 10.15957/j.cnki.jjdl.2015.07.022. 